\section{The in vivo antioxidant effect of vitamin C on hemogram in Paraquat treated male rats (rattus norvegicus)}

\author{
Benjamin Nnamdi Okolonkwo, ${ }^{1}$ \\ Chukwubuike Udoka Okeke, ${ }^{2}$ \\ Victor lbharokhonre ${ }^{3}$
}

'Department of Medical Laboratory

Sciences, Faculty of Science, Rivers State

University of Science and Technology,

Nkpolu - Orowuroko, Port-Harcourt,

Rivers State; ${ }^{2}$ Department of Prosthesis and Orthopaedic Technology, School of Health Technology, Federal University of Technology Owerri, Imo State; ${ }^{3}$ Labdata Diagnostics and Services, Rumuigbo, Obio-Akpor L.G.A. Rivers State, Nigeria

\section{Abstract}

Paraquat $(\mathrm{PQ})$ is one of the most used herbicide globally; applied around trees in orchards and between crop rows to control broad-leaved and grassy weeds. Its oxidation results in the formation of superoxides which causes damage to cellular components. In this study, we determined the antioxidant effect vitamin $\mathrm{C}$ has on hemograms [hemoglobin (Hb), packed cell volume (PCV) and total white blood cells count] of rats under these toxic insults. The animals grouped (A-D), comprising subgroups without vitamin $\mathrm{C}\left(\mathrm{A}_{1}, \mathrm{~B}_{1}, \mathrm{C}_{1}\right.$, $\left.\mathrm{D}_{1}\right)$ and subgroups on vitamin $\mathrm{C}\left(\mathrm{A}_{2}, \mathrm{~B}_{2}, \mathrm{C}_{2}\right.$, $D_{2}$ ), received different sub-lethal doses of $P Q$ administered intraperitoneally monthly to the animals over a period of three months. The $\mathrm{Hb}$ values obtained were significantly reduced $(\mathrm{P} \leq 0.05)$ at month 1 and $(\mathrm{P} \leq 0.001)$ at months 2 and 3 . These changes became more pronounced with increased dose and time. Vitamin $C$ treated subgroups $\left(B_{2}, C_{2}\right.$ and $\left.D_{2}\right)$ had better $\mathrm{Hb}$ values than those without it $\left(\mathrm{B}_{1}\right.$, $\mathrm{C}_{1}$ and $\mathrm{D}_{1}$ ) but the values were still significantly low when compared to the control subgroups $\left(A_{1}\right.$ and $\left.A_{2}\right)$. This same trend was observed in the PCV results obtained. The Control subgroups showed that vitamin $\mathrm{C}$ treated subgroup $\left(A_{2}\right)$ had a more improved hemogram values than subgroup on water only $\left(A_{1}\right)$, but they were all higher than that of the test subgroups. These PQ induced anaemia were ameliorated by the subsequent administration of vitamin $\mathrm{C}$, and continuous treatment with vitamin $\mathrm{C}$ restored the health status of the animals so treated.

\section{Introduction}

Paraquat (PQ), a controversial herbicide, is one of the most used total contact herbicide globally; it is applied around trees in orchards and between crop rows to control broad-leaved and grassy weeds. ${ }^{1}$ Because $\mathrm{PQ}$ has a redox potential of $-446 \mathrm{mV}$, any reducing agent with sufficient energy can donate an electron to the bipyridylium divalent cation $\left(\mathrm{PQ}^{2+}\right)$, to form a free radical $\left(\mathrm{PQ}^{+}\right)$, which its oxidation results in the formation of the original $\mathrm{PQ}^{2+}$ and a transfer of the released electron to oxygen which subsequently leads to the formation of toxic superoxides called Reactive Oxygen Species which when in excess escapes the electron transport chain and causes damage to cellular components. ${ }^{2}$

The hemograms [hemoglobin ( $\mathrm{Hb})$, packed cell volume (PCV) and total white blood cells count (T-WBC)] are hematological parameters used in accessing blood functionality in health and diseased state. ${ }^{3}$ Few of its primary functions are to detect anaemia, polycytaemia, leucocytosis, leucocytopenia, etc. They also contribute in assessing transportation, distribution, regulation and protection of body fluids. ${ }^{3}$

Toxic substances, such as $\mathrm{PQ}$, through the formation of oxygen free radicals (ROS) results in the destruction of cellular components leading to hemolysis (destruction of red blood cells), ${ }^{4}$ production failure (by attacking stem cells), ${ }^{5}$ transportation failure (by chelating iron, other metals and proteins involved in cellular functions), ${ }^{6}$ regulatory and protective failure (by affecting leucocytes and platelet production). ${ }^{6}$

Vitamin C, a potent water soluble vitamin, has been shown to function as an antioxidant. It has affinity for many free radicals, ${ }^{7}$ thereby minimizing the damage caused by oxidative stress. Vitamin C directly scavenges ROS with and without enzyme catalysts and can indirectly scavenge them by recycling other antioxidants (e.g. tocopherol) to the reduced form. ${ }^{8,9}$ By reacting with activated oxygen more readily than any other aqueous components ascorbate protects critical macromolecules from oxidative damage. ${ }^{8}$ In cells, vitamin $\mathrm{C}$ is maintained in its reduced form by reacting with glutathione, which can be catalyzed by protein disulphide isomerase and glutaredoxins. ${ }^{10,11}$ In addition to its direct antioxidant effects, vitamin $C$ is also a substrate for the antioxidant enzyme ascorbate peroxidase, a function that is particularly important in stress resistance in plants. $^{12,13}$

Because of this potent functionality of vitamin C, this study was geared towards assessing the acceptability of vitamin $\mathrm{C}$ as an adjunct in treatment and management of Paraquat toxicity cases.
Correspondence: Benjamin Nnamdi Okolonkwo, Department of Medical Laboratory Sciences, Faculty of Science, Rivers State University of Science and Technology, Nkpolu - Orowuroko, Port-Harcourt, Rivers State, Nigeria.

Tel. +234.805.614.1653.

E-mail: benbruceph@yahoo.com

Key words: Paraquat, vitamin C, antioxidant, hemogram, rats.

Contributions: BNO, as the lead author, was involved in the research proper, analyzing the samples and making sure that all went well with the study; CUO, carried out the statistical analysis and assisted in proof reading of the materials before publication; VI, performed the serious statistical areas that needed in-depth analysis and designed the graphical representation of the data for visual understanding.

Conflict of interests: the authors declare no potential conflict of interests.

Received for publication: 14 February 2013.

Revision received: 6 May 2013.

Accepted for publication: 14 May 2013.

This work is licensed under a Creative Commons Attribution NonCommercial 3.0 License (CC BYNC 3.0).

(C) Copyright B.N. Okolonkwoet al., 2013 Licensee PAGEPress, Italy

Journal of Xenobiotics 2013; 3:e7

doi:10.4081/xeno.2013.e7

\section{Materials and Methods}

\section{Materials}

\section{Rats}

A total of 96 male Albino rats (Rattus norvegicus), weighing between $180-220 \mathrm{~g}$ [average body weight (BW) $0.2 \pm 0.02 \mathrm{~kg}$ ], were used for the study. Prior to experimentation, all the animals were allowed two weeks to acclimatize to their environment during which period they all had free access to tap water and were fed with pelletized finisher feed (ad libitum), all with negligible vitamin $\mathrm{C}$ content.

\section{Paraquat}

The paraquat used was purchased as a liter volume of $20 \% \mathrm{w} / \mathrm{v}$ solution with the trade name Dizmazone (Dizengoff W.A. Ltd, Lagos, Nigeria) properly sealed in an opaque plastic container. It was kept at room temperature and during use proper caution was taken to avoid fire, spillage or poisoning.

\section{Vitamin C}

Pure vitamin C (1000 mg) caplets from 
Mason Natural ${ }^{\circledR}$ Trade name of Mason Vitamins, Inc. (Miami Lakes, FL, USA), were used for the research.

\section{Methods}

Two $\mathrm{mL}$ of different sub-lethal doses of the toxicant (PQ) was intraperitoneally (ip) administered to the animals, under anaesthetics, ${ }^{14}$ in different dosed subgroups $-\mathrm{A}_{1}, \mathrm{~A}_{2}(0.0$ $\mathrm{g} / \mathrm{kg}) ; \mathrm{B}_{1}, \mathrm{~B}_{2}(0.02 \mathrm{~g} / \mathrm{kg}) ; \mathrm{C}_{1}, \mathrm{C}_{2}(0.04 \mathrm{~g} / \mathrm{kg})$ and $\mathrm{D}_{1}, \mathrm{D}_{2}(0.06 \mathrm{~g} / \mathrm{kg})$ - on biweekly basis for 3 months [subgroups $\mathrm{A}_{1}$ and $\mathrm{A}_{2}$ was given $2 \mathrm{~mL}$ of $0.9 \mathrm{~N}$ normal saline (ip) in conformity with international standard in checking injection sites reaction]. The subgrouped animals were designated into: i) for non-vitamin $\mathrm{C}$ treatment; and ii) for vitamin $\mathrm{C}$ treatment, as indicated in Table 1.

Subsequently, vitamin C solution (200 $\mathrm{mg} / \mathrm{L}$ ) was prepared in place of water and were provided to the animals in drinking water bottles with glass sipper tubes for rats in subgroups $2\left(\mathrm{~A}_{2}, \mathrm{~B}_{2}, \mathrm{C}_{2}\right.$ and $\left.\mathrm{D}_{2}\right)$, while ordinary drinking water with negligible vitamin $\mathrm{c}$ content was provided to the animals in subgroups $1\left(A_{1}, B_{1}, C_{1}\right.$ and $\left.D_{1}\right)$ all through the study period (Table 1). The water and vitamin $C$ bottles were refilled at least trice daily irrespective of the volume of water or vitamin $\mathrm{c}$ remaining in the in-use bottles. It will be note worthy to state that at month 3 , the food and water consumption by the rats were affected by $P Q$ intoxication, mainly the subgroups dosed $0.06 \mathrm{~g} / \mathrm{kg}$ BW without vitamin $\mathrm{C}$ treatment $\left(\mathrm{D}_{1}\right)$.

On monthly intervals, 4 animals per subgroup were selected, anaesthetized with gaseous isoflurane anaesthetic machine, the induction chamber was prefilled with $4 \%$ isoflurane and oxygen $(0.6 \mathrm{~L} / \mathrm{min})$. The rats were placed in the induction chamber and observed for signs of lateral recumbence, steady breathing and no attempt to right itself when the induction chamber is slightly tilted, only then is it anaesthetized enough for transfer to the mask on the rodent breathing circuit. Open the lid of the induction chamber and quickly check for absence of the pedal reflex..$^{15}$ If present, $3 \mathrm{~mL}$ of blood sample were collected using $23 \mathrm{G}$ needle attached to $5 \mathrm{~mL}$ syringe and the blood samples collected were decanted into Ethylenediaminetetracetic acid containers using cardiac puncture procedures. ${ }^{14}$ After mixing, the samples were ready for the hematological estimations of $\mathrm{Hb}, \mathrm{PCV}$ and T-WBC using cyanmethemoglobin method, microhematocrit method and improved Neubaur counting chamber method, respectively. ${ }^{5}$

\section{Animal care}

We do affirm that in carrying out this research that The Nigerian Institutional and National Guide for the care and use of laboratory animals were followed.

\section{Data computation}

The Excel (2007) window's package and two-way analysis of variance (ANOVA) statistical methods were used for the result analysis, with levels of significance measured at $\mathrm{P}<0.05$ and 0.001 respectively.

\section{Results}

The T-WBC counts of the individual subgroups for the 3 months study were presented in Figure 1 above. The results obtained indicated that, from months 1-2, there existed no observable effect by either $P Q$ or vitamin $C$ on T-WBC values. The control and tests subgroups values were similar, with negligible dose and time effects on either the subgroups on $\mathrm{PQ}$ alone $\left(B_{1}, C_{1}\right.$ and $\left.D_{1}\right)$ or the subgroups which in addition to $\mathrm{PQ}$ insult received vitamin $\mathrm{C}\left(\mathrm{A}_{2}\right.$,
$B_{2}, C_{2}$ and $D_{2}$ ). It is either that $P Q$ toxicity does not trigger immune response or that the dose and duration of toxicity was not enough for such effect to be noticeable. Another reason could be that the route of administration of $\mathrm{PQ}$ (ip) hinders humoral or passive immune response. At month 3, a somewhat increased difference existed between the control subgroups and the test subgroups which were dose dependent at $\mathrm{P} \leq 0.05$, but the within subgroups comparison indicated no difference between the $\mathrm{PQ}$ only treated subgroups $\left(\mathrm{B}_{1}, \mathrm{C}_{1}\right.$ and $\mathrm{D}_{1}$ ) and the subgroups which in addition to $\mathrm{PQ}$ insult received vitamin $\mathrm{C}\left(\mathrm{A}_{2}, \mathrm{~B}_{2}, \mathrm{C}_{2}\right.$ and $D_{2}$ ). This supported the summation that further studies with longer dose and time effect needs to be carried out to completely determine what will happen on the T-WBC studied.

The $\mathrm{Hb}$ mean values obtained (Figure 2) shows that $\mathrm{PQ}$ toxicity actively reduced the $\mathrm{Hb}$ levels of the test subgroups $\left(\mathrm{B}_{1}, \mathrm{~B}_{2}, \mathrm{C}_{1}, \mathrm{C}_{2}, \mathrm{D}_{1}\right.$

Table 1. Treatment chart for the subgroups.

\begin{tabular}{l} 
Group A: Control group given $0.0 \mathrm{~g} / \mathrm{kg} \mathrm{PQ}$ and divided into two subgroups \\
A1: subsequently received water and feed \\
A2: subsequently received vitamin C solution $(1000 \mathrm{mg} / \mathrm{L})$ \\
Group B: Test group given $0.02 \mathrm{~g} / \mathrm{kg} \mathrm{PQ}$ and divided into two subgroups \\
B1: subsequently received water and feed \\
B2: subsequently received vitamin C solution ( $1000 \mathrm{mg} / \mathrm{L})$ and feed \\
Group C: Test group given $0.04 \mathrm{~g} / \mathrm{kg} \mathrm{PQ}$ and divided into two subgroups \\
C1: subsequently received water and feed \\
C2: subsequently received vitamin C solution $(1000 \mathrm{mg} / \mathrm{L})$ and feed \\
\hline Group D: Test group given $0.04 \mathrm{~g} / \mathrm{kg} \mathrm{PQ}$ and divided into two subgroups \\
D1: subsequently received water and feed \\
D2: subsequently received vitamin C solution $(1000 \mathrm{mg} / \mathrm{L})$ and feed \\
\hline PQ, Paraquat.
\end{tabular}

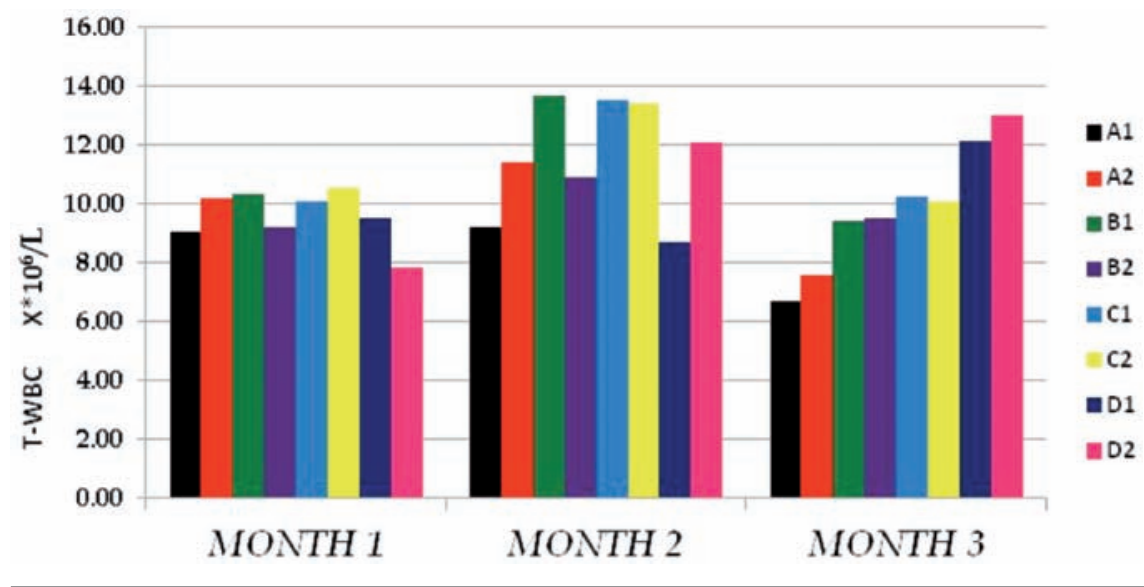

Figure 1 . The total white blood cells count $\left(\mathrm{T}-\mathrm{WBC} \times 10^{6} / \mathrm{L}\right)$ mean values of the different subgroups for the 3 months study period. 
and $\mathrm{D}_{2}$ ) when compared to the control subgroups $\left(\mathrm{A}_{1}\right.$ and $\left.\mathrm{A}_{2}\right)$ at $\mathrm{P} \leq 0.05$ (month 1 ) and $\mathrm{P} \leq 0.001$ (months 2 and 3 ). The reduction was found to be more on the subgroups that received $\mathrm{PQ}$ (ip) only (B1, C1 and D1) than the subgroups which in-addition to $\mathrm{PQ}$ insult received vitamin $\mathrm{C}\left(\mathrm{B}_{2}, \mathrm{C}_{2}\right.$ and $\left.\mathrm{D}_{2}\right)$. We noticed that the effect was both dose and time dependent and also that there were an existing interaction between the dose effect and the time of exposure. The within subgroups comparison showed that the subgroups which in-addition to $\mathrm{PQ}$ insult received vitamin $\mathrm{C}\left(\mathrm{B}_{2}, \mathrm{C}_{2}\right.$ and $\left.\mathrm{D}_{2}\right)$ had a higher $\mathrm{Hb}$ values than the subgroups that received $\mathrm{PQ}$ (ip) only (B1, C1 and D1), indicating that vitamin $\mathrm{c}$ improved their $\mathrm{Hb}$ level even with the dose and time of exposure effects.

The PCV mean values obtained in Figure 3 also followed the same pattern with that of $\mathrm{Hb}$ in Figure 2. Reduction in the volume of the red cells of test subgroups $\left(B_{1}, B_{2}, C_{1}, C_{2}, D_{1}\right.$ and $D_{2}$ ) from months 1 to 3 as compared to that of the control subgroups $\left(A_{1}\right.$ and $\left.A_{2}\right)$ within the same period of time signifies that $P Q$ toxicity actively affected the red cells number and functionality through hemolysis, membrane enzyme disruption, etc. Also we observed that these effects were less in vitamin c treated subgroups than the subgroups on $\mathrm{PQ}$ insult only indicating that vitamin $\mathrm{C}$ has a life saving effect on cells that were placed under toxic insult. The data obtained also showed that there was an interaction between dose of $P Q$ given and the time of exposure. The higher the dose given and the time of exposure the more the PCV mean values were reduced.

\section{Discussion}

$\mathrm{PQ}$ is a well known herbicide that has been extensively used for the defoliation of weeds in farmland, recreational, public and industrial sites. ${ }^{1}$ Its toxicity effect is initiated by its ability to form ROS causing disruption of cell membrane functionality and possibly cell death. ${ }^{16}$ Vitamin $c$ has been shown to scavenge these ROS with or without enzyme catalysis thereby restoring cell functionality. 9,8

In this study, we investigated the ameliorative effect of vitamin $\mathrm{C}$ on $\mathrm{PQ}$ toxicity using hematological cells that are easily affected by PQ toxicity. We hypothesized that T-WBC and red blood cells when subjected to toxic insult in vivo will respond easily, and that subsequent and continuous administration of vitamin $\mathrm{C}$ will arrest these ROS and restore cell functionality in the affected animals. To investigate this, we choose, PCV, Hb and T-WBC parameters, reason being that they are easily affected by hemolysis, inflammation, enzyme deactivation, etc occasioned by toxic insult, and also they respond quickly to the repairing and restoring effect of vitamin c on cell membrane, cytosol and endoplasmic enzyme activities.

The results of the mean T-WBC counts (Figure 1) indicated that there were no observable changes in the values obtained from months 1-2 in both the dose and time of exposure effects in the subgroups treated. These was corroborated by the results from other studies where the changes observed in T-WBC of animals under PQ insult treated with various antioxidant were not significantly different from that of the control animals used. ${ }^{17,18} \mathrm{At}$ month 3 , there seemed to be a noticeable increase in the T-WBC mean values of the test subgroups when compared to the control, but the within subgroup comparison showed no difference between the vitamin $c$ treated subgroups and those on PQ only. This made us suggest that the dose and time of exposure may not have been enough to conclusively determine the immune cell toxicity effect.

$\mathrm{Hb}$ mean values of the test subgroups (Figure 2) were significantly lower than the control subgroups at $\mathrm{P} \leq 0.05$ (month 1 ) and $\mathrm{P} \leq 0.001$ (months 2 and 3), respectively. These test subgroups reduction in $\mathrm{Hb}$ mean values was found to be both dose and time of exposure dependent, with the subgroups on vitamin $\mathrm{c}$ having much better $\mathrm{Hb}$ values than that

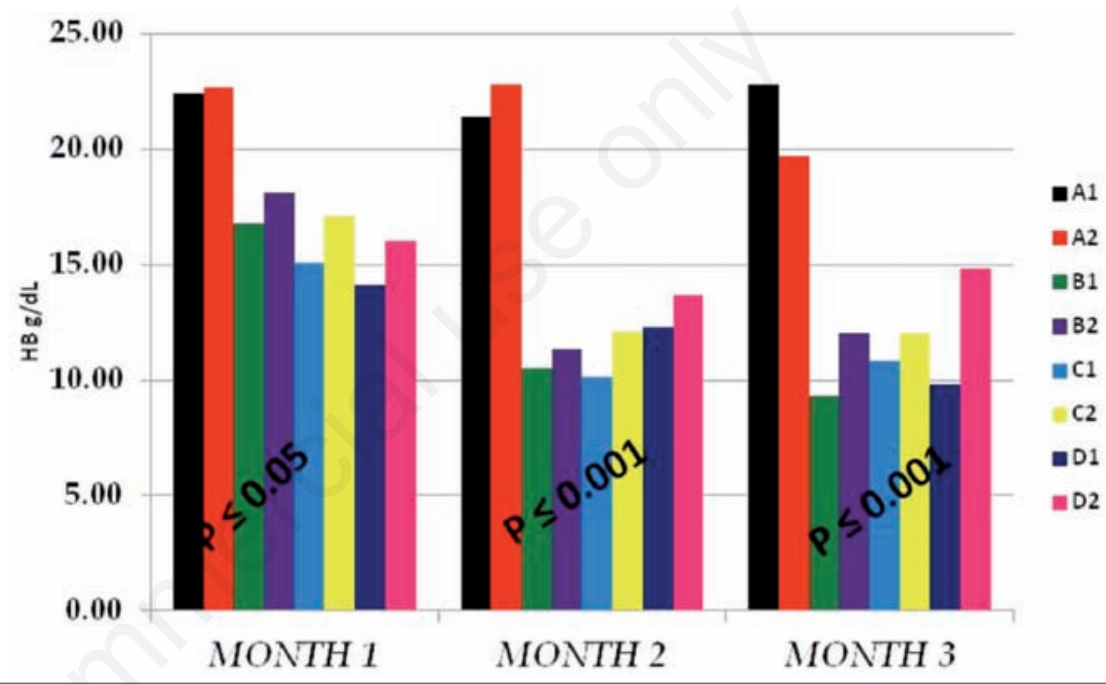

Figure 2. The hemoglobin ( $\mathrm{HB} \mathrm{g} / \mathrm{dL}$ ) mean values of the different subgroups for the 3 months study period.

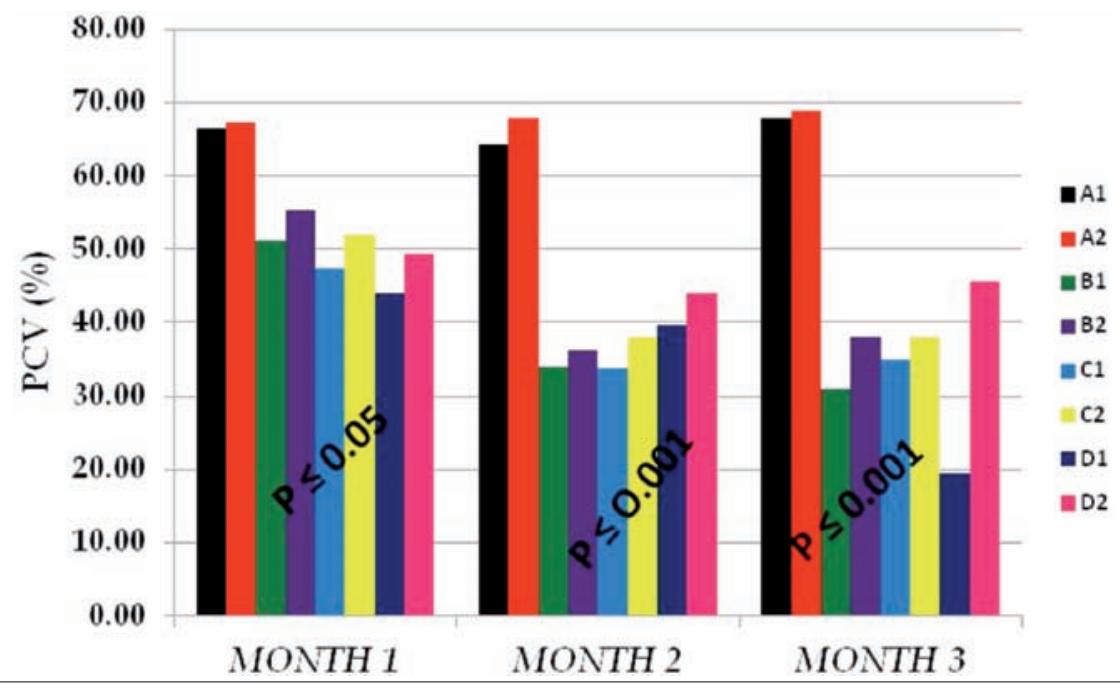

Figure 3. The packed cell volume (PCV \%) mean values of the different subgroups for 3 months study period. 
of the test subgroups on PQ treatment only. Also the vitamin $c$ treated control subgroup $\left(\mathrm{A}_{2}\right)$ has a better improved $\mathrm{Hb}$ than the negative control $\left(A_{1}\right)$. This interaction between the dose given and the time of exposure effects where supported by the findings that vitamin $\mathrm{c}$ confers some level of Protection: Prevention, Interception and Repair, thereby stopping hemolysis and destruction of red cells. ${ }^{17-20}$ Also the work on Dapsone treatment indicated that vitamin $\mathrm{C}$ alongside vitamin $\mathrm{E}$ has a protective effect on the erythrocyte against haemolysis caused by dapsone in patient with dermatitis herpetiformis. ${ }^{21}$

Similarly, the PCV mean values (Figure 3) obtained followed the same pattern with that of the $\mathrm{Hb}$. The reduction in volume were as a result of hemolysis, lipid peroxidation, superoxide formation and elevated nutrient catalysis occasioned by the toxic insult, ${ }^{2}$ these effects were dose and time dependent, ${ }^{22}$ occurring at the expense of cellular reducing equivalent, such as nicotinamide adenine dinucleotide phosphate-oxidase, and having consequences in other metabolic processes. ${ }^{22-24}$ These processes led to the phenotypic observations like loss of weight, inability to feed, hair loss, redness of the eyes and high incidence of labored breathe among test subgroups at higher doses ( 0.04 and $0.06 \mathrm{~g} \mathrm{PQ} / \mathrm{kg}$ body weight), especially on the subgroups on $\mathrm{PQ}$ dose only. This same subgroups recorded high incidence of death among test animals.

Finally, the dosage, time of exposure and their interaction effects observed on the $\mathrm{Hb}$ and PCV mean values obtained from test subgroups on $\mathrm{PQ}$ only and those that received vitamin $c$ during $P Q$ insult indicates that truly vitamin $\mathrm{c}$ has the capability to reduce or limit toxic insult occasioned by $\mathrm{PQ}$ or any other xenobiotics. Therefore we suggest that vitamin $\mathrm{C}$ treatment should be incorporated into the first-line regimen on cases of toxicity reported in emergency health facilities.

\section{Conclusions}

This study has demonstrated the life saving effects of antioxidant (vitamin C) on the chronic toxic insults of $P Q$ administered intraperitoneally to rats.

Exposure of rats to $\mathrm{PQ}$ induced massive anaemia and mild leucocytosis that were dose and time dependent, but the subsequent admin- istration of the antioxidant (vitamin C) ameliorated these effects and normalized the hemograms depending on the dose and duration of the treatment. It is evident that vitamin $\mathrm{C}$ continuous administration during toxic insult should be one of the first-line treatments given to patients, and that it should be extended even after patient's recovery to completely repair the cells and tissues that were damaged.

\section{References}

1. IPCS-INCHEM. International programme on chemical safety. Environmental Health Criteria 39. Paraquat and diquat; 1984. Available from: http://www.inchem.org/ documents/ehc/ehc/ehc39.htm

2. Punchard NA, Kelly FJ, eds. Free radicals: a practical approach. Oxford: IRL Press; 1996.

3. Bain BJ. Blood cells: a practical guide. 2nd ed. Malden, MA: Blackwell Science; 1995.

4. Dacie JV, Lewis SM. Practical haematology. 8th ed. Edinburgh: Churchill Livingstone; 1994.

5. Cheesbrough M. Haematological tests: district laboratory practice in tropical countries. Part 2. Cambridge: Cambridge University Press; 2000. pp 267-387.

6. Evantt BL, Gibbs WN, Lewis SM, McArthur JR. Fundamental diagnostic haematology - anaemia. World Health Organization \& US Department of Health \& Human Services, CDC 2nd edition. WHO, 1211, 27. Geneva: WHO Publications; 1992.

7. Foyer C. Ascorbic acid. In: RG Alscher, JL Hess, eds. antioxidants in higher plants. Boca Raton, FL: CRC Press; 1993. pp 31-58.

8. Asada K. Ascorbate peroxidase - hydrogen peroxide - scavenging enzyme in plants. Physiol Plant 1992;85:235-41.

9. Loewus FA. Ascorbic acid and its metabolic products. In: J Preiss, ed. The biochemistry of plants. New York: Academic Press; 1988. pp 85-107.

10. Meister A. Glutathione - ascorbic acid antioxidant system in animals. J Biol Chem 1994;269:9397-400.

11. Wells W, Xu D, Yang Y, Rocque P. Mammalian thioltransferase (glutaredoxin) and protein disulphide isomerase have dehydroascorbate reductase activity. J Biol Chem 1990;265:15361-4.
12. Shigeoka $\mathrm{S}$, Ishikawa $\mathrm{T}$, Tamoi $\mathrm{M}$, Miyagawa Y, Takeda T, Yabuta Y, et al. Regulation and function of ascorbate peroxidase isoenzymes. J Exp Bot 2002;53: 1305-19.

13. Carr A, Frei B. Does vitamin c act as a prooxidant under physiological conditions? Faseb J 1999;13:1007-24.

14. Animal Care and Ethics Committee. Blood collection in rodents and rabbits. Newcastle: ACEC, University of Newcastle; 1999. Available from: http://www.newcastle.edu. au/research/animal/revision/acec 29.pdf Accessed: June 2007.

15. Diel KH, Hull R, Morton D, Pfister R, Rabemampianina Y, Smith D, et al. A good practice guide to the administration of substances and removal of blood including routes and volumes. J Appl Toxicol 2001; 21:15-23.

16. Sies H. Strategies of antioxidant defense. Eur J Biochem 1993;215:213-9.

17. Buettner GR. The pecking order of free radicals and antioxidants, lipid peroxidation, alphatocopherol and ascorbate. Arch Biochem Biophys 1993;300:535-43.

18. Beyer RE. The role of ascorbate in antioxidant protection of biomembranes: interaction with vitamin $\mathrm{E}$ and coenzyme Q. J Bioenerg Biomembr 1994;26:349-58.

19. Wefers $\mathrm{H}$, Sies $\mathrm{H}$. The protection by ascorbate and glutathione against microsomal lipid peroxidation is dependent on vitamin E. Eur J Biochem 1988;174:353-7.

20. Thakur MI, Srivastava US. Vitamin-E metabolism and its application. Nutr Res 1996;16:1767-809.

21. Prussick R, Ali MA, Rosenthal D, Guyatt G. The protective effect of vitamin $\mathrm{E}$ on the hemolysis associated with dapsone treatment in patients with dermatitis herpetiformis. Arch Dermatol 1992;128:210-3.

22. Bachur NR, Gordon SL, Gee MV. A general mechanism for microsomal activation of quinine anticancer agents to free radicals. Cancer Res 1978;38:1745-50.

23. Kappus H, Sies H. Toxic drug effects associated with oxygen metabolism, redox cycling and lipid peroxidation. Experiential 1981;37: 1233-41.

24. Thor H, Smith MT, Hartzell P, Bellomo G, Jewell SA, Orrenius S. The metabolism of menadione (2-metyl-1, 4-naphtoquinone) by isolated hepatocytes. J Biol Chem 1982;257:12419-25. 